\title{
Assessment of deicing salt storage and distribution as a salinization point source: the influence of permitting standards on water quality
}

Rebecca Tharp ${ }^{1 *}$ and Dana Allen ${ }^{2}$

\begin{abstract}
Background: Road deicing salts are impacting freshwater ecosystems in snowy regions worldwide. Rock salt (typically sodium chloride) is transported to and stored in regional facilities that operate year-round and are continuous potential sources of chloride discharge to adjacent water bodies, resulting in different impacts to aquatic ecosystems than chloride pollution from spatially diffuse road networks. The regulatory tools and associated monitoring regimes used by state and federal agencies related to permitting of these facilities is inconsistent. Selection of the regulatory standards and monitoring location in the receiving water body (and how the definition of 'receiving water body' is applied) can have a significant influence on the measured or modeled impact of a facility on aquatic ecosystems. Additionally, selection of the monitored media (surface water, soil pore water, shallow ground water, or vegetation) can further influence findings, resulting in inconsistent conclusions of environmental impact and potentially allow exceedances of regulatory thresholds of chloride. This study evaluates chloride pollution from salt loading over two years from a state-permitted salt storage and transport facility in Shelburne, Vermont, USA to an adjacent wetland and river that drains to Lake Champlain. Water quality results and modeled assumptions made by the permittee were compared to monitoring data at two discharge points from the site including a drainage channel downstream of the site's stormwater pond and at a shallow ground water seep below the rail car unloading area.

Results: Results indicate elevated chloride concentrations (average of 243 and $643 \mathrm{mg} \mathrm{L}^{-1}$ ) at the discharge points to the receiving water body, in conflict with findings from annual permittee assessments. Soil cores taken in the wetland in the vicinity of the control and two discharge points also indicate elevated $\mathrm{Cl}^{-}(p \leq 0.035)$ and $\mathrm{Na}^{+}(p \leq 0.0006)$. Samples of Tsuga canadensis at the discharge points and at the control site indicate elevated chloride in plant tissues.

Conclusions: Determination of exceedances of chronic and acute standards vary based on the sampling location and medium, indicating a need for consistency and outcome-based monitoring point selection criteria and a move away from reliance on self-reporting by permittees.
\end{abstract}

Keywords: Wetland pollution, Deicing salt runoff, Salt storage facility, Chloride pollution, Salinization, Urban stormwater, Regulating chloride

*Correspondence: becky@justwaterconsulting.com

1 Just Water Consulting, Vermont, USA

Full list of author information is available at the end of the article

\section{Background}

Freshwater resources across the world are increasingly being threatened by salinization linked to anthropogenic activities (Hintz and Relyea 2019; Herbert et al. 2015; Cañedo-Argüelles et al. 2013; Dugan et al. 2017). Significant contributors include mining, sea level rise 
(attributable to climate change), agriculture, and application of deicing salts associated with roadways and parking lots (Herbert et al. 2015; Dugan et al. 2017; Castillo et al. 2018; Albecker and McCoy 2017; Müller and Gächter 2012). This last activity has been recognized as the leading source of chloride loading to freshwater resources in urbanized areas in regions that experience freezing winters (Panno et al. 2006; Howard and Maier 2007; Williams et al. 2000). In the Midwest and northeastern United States, many streams are at risk of becoming toxic to aquatic life within the next 100 years as a result of deicing salt inputs (Kaushal et al. 2005).

Over 70\% of the roadways in the United States are considered to be in "snowy" regions that receive more than twelve centimeters each year (Labashosky 2015). The use of deicing salts on road networks has reduced average accident rates by 87 and $78 \%$ on 2-lane and multi-lane roads respectively, making it an important safety precaution for road maintenance (Hanbali and Kuemmel 1993). Due to its success in reducing slippery road conditions, salting roads for deicing has expanded considerably in the United States since the 1940s when sales of salts for highway applications was 0.15 metric tons, increasing to over 18 million metric tons annually in 2005 (Jackson and Jobbágy 2005). Recent figures (2015) from the United States Geological Survey (USGS) estimate national volumes of road salt application for transportation at 22.7 metric tons per year (Bolen 2015).

The most commonly used road salt is sodium chloride $(\mathrm{NaCl})$ as it is the least expensive deicer and is effective at temperatures above $-10{ }^{\circ} \mathrm{C}$. The temperature at which $\mathrm{NaCl}$ is no longer effective at restricting the freezing of water (its eutectic point) is $-21^{\circ} \mathrm{C}$. Other salts including calcium chloride $(\mathrm{CaCl})$ and magnesium chloride $(\mathrm{MgCl})$ have lower eutectic points and therefore are useful for deicing when temperatures are very low. However, $\mathrm{MgCl}$ and $\mathrm{CaCl}$ are more costly and can be more toxic to aquatic communities, generally rendering them less commonly used (Kotalik et al. 2017; Kelly et al. 2010).

Deicing salts readily disassociate into their constituent ions once dissolved in water. The chloride $\left(\mathrm{Cl}^{-}\right)$ion is chemically stable and does not readily transform through biological or chemical processes once in the environment, making it a persistent contaminant of concern in freshwater ecosystems (Kelly et al. 2010; Ledford et al. 2016; Mason et al. 1999; Reddy and DeLaune 2008). Numerous studies demonstrate a variety of water quality impacts associated with road salt use. Salinization of fresh waters can lead to metal mobilization, acidification, inhibition of denitrification, alteration of phosphorus cycling between sediments and their overlying water column, and physical changes to soil structure. These physical and chemical impacts have direct influence on ecological communities including alteration of plant and wildlife species diversity and composition, and reduced survival, growth, richness and abundance, and reproduction of aquatic species (Kaushal et al. 2005; Corsi et al. 2010; Meter and Swan 2014; Brown and Yan 2015; Hintz and Relyea 2019).

Sub-lethal impacts have been described for a number of species, including at the low end of the food web with zooplankton where chloride influences breeding, grazing, and drift behavior and is often impactful at much lower concentrations than for some higher level animals (Crowther and Hynes 1977; Meter et al. 2011, 2012). For example, zooplankton represent an important food source for fish and are highly influential to food web linkages between the aquatic and terrestrial environment (Hintz and Relyea 2019; Liao et al. 2002). One study found a population decrease by more than $50 \%$ in concentrations of $469 \mathrm{mg} \mathrm{L}^{-1}$ chloride over 2 weeks (Petranka and Francis 2013). Because many species of zooplankton breed and feed at the sediment/water interface where chloride levels tend to be higher due to the greater density of salt-saturated water, their exposure in that zone of higher salinity water may have population impacts that exceed what is indicated by monitoring data taken in the pelagic zone (Novotny and Stefan 2012; Ellis et al. 1997; Eyles and Meriano 2010; Gillis 2011).

Based on biological impact research, the US EPA developed guidelines for acute and chronic levels of chloride pollution in fresh water ecosystems of $860 \mathrm{mg} \mathrm{L}^{-1}$ (as a 1-h average) and $230 \mathrm{mg} \mathrm{L}^{-1}$ (as a 4-day average) not to be exceeded in a 3 -year period (US EPA 1988). These guidelines have been adopted by US states in some cases. However, use of these guidelines to develop water quality regulations varies widely.

While the impact of deicing salts after they have been applied to impervious surfaces has gained attention from the scientific community and some regulatory bodies (Dugan et al. 2017; Kelly et al. 2010; Ramakrishna and Viraraghavan 2005; OWRC/SCCGW Salt Storage Workgroup 2013), centralized salt storage facilities served by intermodal transport (shipping containers transported by boat, rail, or truck) are less studied, loosely regulated, and poorly spatially characterized, even as they represent a continuous point source of potential salt discharge. Storage facilities, unlike spatially diffuse roadways where deicing salt is applied seasonally, represent year-round, concentrated, and localized pollutant inputs that could be tracked and monitored to better understand salt movement in soils, vegetation, and waterways, as well as long term impacts to the immediate receiving water bodies (Highway Deicing and Calcium Committee 1991). While some regulatory authorities have adopted ordinance language to control deicing salt storage facilities proximity 
to surface waters, discharge methods, storage, handling, and good housekeeping procedures, application of those standards remains variable. Even where controls are in place, methods for determining allowable discharges are inconsistent (OWRC/SCCGW Salt Storage Workgroup 2013).

Jurisdictions regulate storage facilities through a variety of tools, including stormwater programs (either stateor National Pollutant Discharge Elimination System (NPDES)-based), or through a combination of stormwater and drinking water, groundwater, or aquifer protection regulations (OWRC/SCCGW Salt Storage Workgroup 2013). Determining allowable pollutant export concentration and loading, as well as siting and housekeeping standards, depends significantly on the chosen program. Despite differences in regulatory approach, chloride surface water standards are similar across jurisdictions and are commonly aligned with the US EPA's recommendation (US EPA 2020). There is uncertainty about the ability for existing regulatory frameworks without dedicated chloride discharge standards from storage facilities to adequately protect water quality to the minimum standard developed by the US EPA (Strobl et al. 2006; Herricks et al. 1985; Prosser et al. 2017).

A 2016 study reviewed water quality monitoring programs and concluded that the complexity of selecting appropriate monitoring locations leaves resource managers at a disadvantage in reviewing proposals and critically evaluating a program's capacity to answer appropriate safety questions. Researchers proposed a "Critical Sampling Points" methodology to alleviate the subjective nature of review (Behmel et al. 2016). Despite that work, monitoring programs remain widely variable across the country and have not adopted a unified approach, leaving water quality monitoring programs in widely ranging states of performance. Adding to the oversight challenges is the reality that self-reported pollution data are the primary source for compliance monitoring information, raising questions about the likelihood for impartiality when a permittee's reporting is the only source of water quality information available for regulators to assess (Shimshack 2014).

This study evaluates the impact of a state stormwater program-permitted deicing salt storage and transportation facility in Vermont, USA. The facility submits annual inspection reports following NPDES standards. The permit specifically indicates control of the discharge of chloride from rock salt, as well as hydrocarbon compounds used on site. The basis used to regulate chloride concentration export associated with stormwater runoff at the site relies on modeling the concentration of chloride at a downstream sentinel water quality monitoring point in the 5th order stream to which it discharges, $800+\mathrm{m}$ from the two permitted discharge points (a stormwater pond outlet and treatment swale overflow level spreader). Selecting sites using standard methods for the identification of monitoring locations (VT DEC 2020), this study analyzes water, soil, and vegetation samples from four locations (including a reference site, two points of discharge, and within an adjacent river) surrounding a deicing salt storage and transportation facility. This study seeks to determine if the regulatory methods and annual inspection requirements used to control pollutant export from the site are effective at protecting water quality in the receiving water bodies.

The data presented here summarize findings from two years of continuous water quality monitoring at two points of discharge from the site including within a wetland along the flow path from the site's stormwater pond discharge outlet and at a shallow groundwater seep directly below the rail spur unloading area at a topographic slope break. A control point was also monitored from a location in close proximity to the facility but outside the drainage area of the site and a fourth point of measurement included levels within the LaPlatte River itself at a location at the upstream point of the site. Soils and vegetation sampling accompanied the water quality monitoring to understand movement and uptake in more stable systems associated with the surface waters.

\section{Materials and methods}

\section{Site description}

A regional deicing salt storage distribution and distribution facility served by rail transportation was constructed in the town of Shelburne, Vermont in 2016 adjacent to a wetland on the banks of the LaPlatte River. The LaPlatte River is a tributary of Lake Champlain, which is phosphorus impaired and subject to total maximum daily load (TMDL) requirements for the nutrient.

Shelburne, Vermont, USA sits in the northwestern portion of the state adjacent to Lake Champlain. The LaPlatte River runs southeast to northwest with a watershed encompassing portions of 5 towns over 137 square kilometers Fig. 1.

The LaPlatte River's watershed land use is dominated by agriculture and forested lands (40 and 39\% respectively) (Milone \& Macbroom Inc 2010), particularly in the upper reaches. Closer to the mouth a 60 -hectare river shore marsh complex dominates. In 2016, the LaPlatte River marsh wetland complex was designated as "Class I" by the Vermont Secretary of the Agency of Natural Resources, indicating that it is "exceptional or irreplaceable in its contribution to Vermont's natural heritage" (Department of Environmental Conservation V 2016). One of less than 10 wetlands in the State to hold such a 


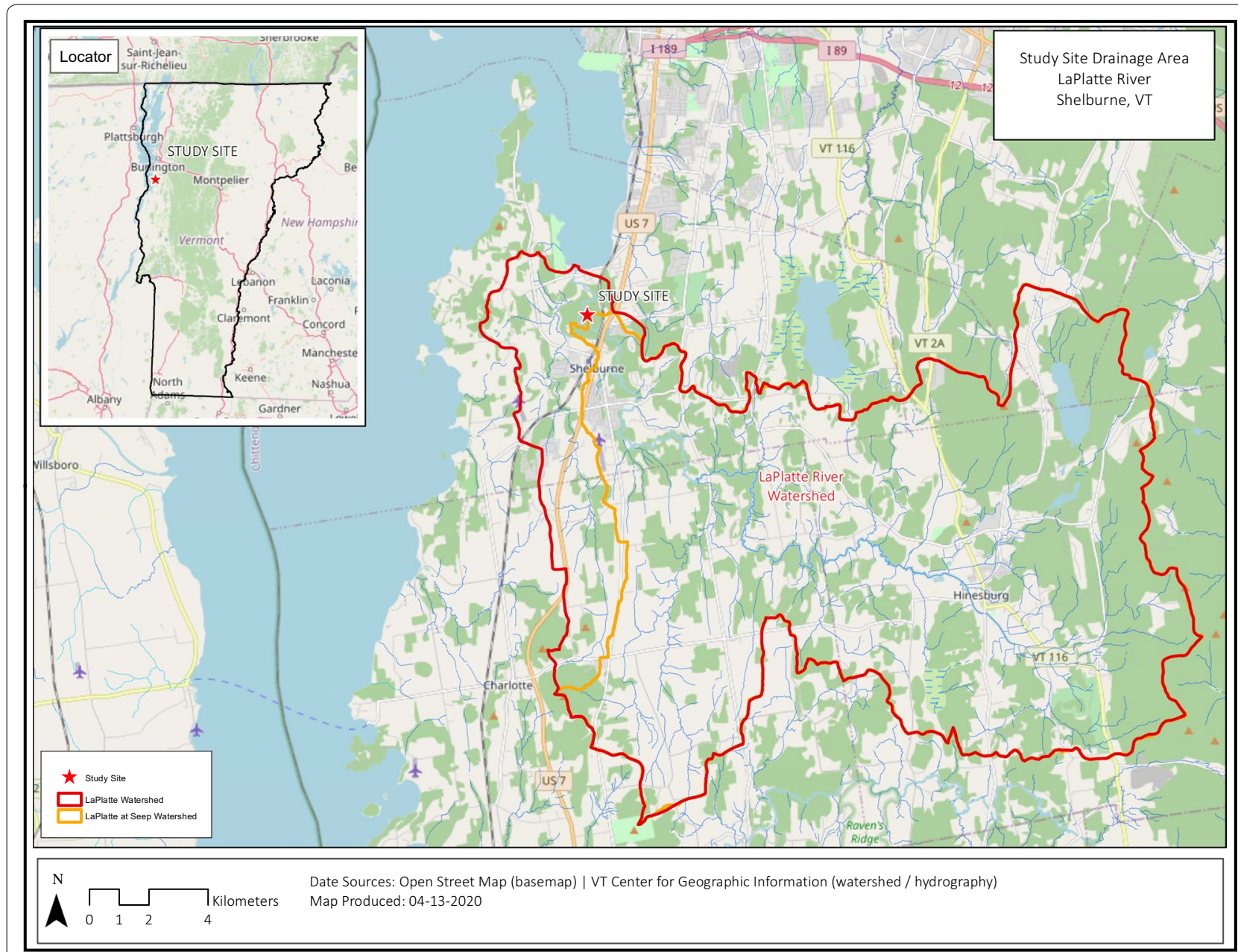

Fig. 1 Locator and LaPlatte River watershed drainage area boundary map shows the study site in Shelburne, VT, USA. Also shown is the watershed boundary for monitoring points within the LaPlatte River itself

classification, the designation as a Class I wetland indicates the quality and importance of the complex.

The Vermont Railway, Inc.'s Shelburne Transload Facility (STF) consists of two $4,750 \mathrm{~m}^{2}$ road salt storage sheds $\left(9,500 \mathrm{~m}^{2}\right.$ total $)$ and an associated rail spur for transportation and unloading of the product on a 14-hectare parcel. Road salt is brought in by rail car, unloaded to storage sheds, and subsequently transferred to trucks and transported to smaller distribution and point-of-use areas. The site was formerly a sandy river terrace comprised primarily of Adams and Windsor loamy sands. It is now approximately $70,000 \mathrm{~m}^{2}$ of impervious surfaces (paved and unpaved). Some of this newly developed surface encroaches on the Class I designated wetland and its $30 \mathrm{~m}$ buffer. Runoff from the site is managed by 2 stormwater features. The primary feature is a wet detention pond with a flow control orifice outlet. Approximately 5.55 hectares (3.74 hectares of impervious surfaces) drains to this feature via swales (pervious paved and impervious rock-lined swales). A small portion of the site $(0.22$ hectares total with 0.17 hectares impervious surfaces) drains to a treatment swale and level spreader on the site's southeastern edge. The wet pond feature discharges to the Class I wetland buffer while the treatment swale discharges to a forested upland area adjacent to the buffer. Note that all measured areas given here were created using aerial imagery from 2018 (Google Satellite data imported to QGIS v3.8) and may differ slightly from measurements listed in permitting documents.

\section{Water quality monitoring}

Three wetland sites were equipped with continuous monitoring devices in 2018. AquaTroll sondes (In Situ, Fort Collins, Colorado, USA) were installed vertically in perforated polyvinyl chloride (PVC) monitoring devices that were embedded $30 \mathrm{~cm}$ into the soil and set atop a bed 
of washed stone (19 mm diameter). PVC tube monitoring devices were wrapped in porous landscape fabric to inhibit excessive sediment influence.

The "Control" site was located in a drainage of similar quality and elevation to the others but that receives no runoff from the STF Fig. 2. In June 2018, the "Control" was equipped with an AquaTroll 200 to measure conductivity and temperature in 15-min increments. In February 2018, the "Pond Outlet" monitoring site was located in the wetland in the effluent pathway from the STF's stormwater pond, approximately $20 \mathrm{~m}$ from the stormwater pond outlet. That site was equipped with an AquaTroll 600 (In Situ, Fort Collins, Colorado, USA) and an associated telemetry tube unit to measure and wirelessly transmit conductivity, temperature, and chloride measurements in 15-min increments. Concurrent with "Pond Outlet" installation, the "Seep" monitoring site was located directly between the LaPlatte River and the rail spur salt unloading area. The steep gradient from the salt unloading area to the River is characterized by a sandy upper layer of soil (Adams and Windsor loamy sands) over a constricting clay layer, resulting in discharge of localized infiltrated surface water to the toe of the slope before overland discharge into the LaPlatte. Water is able to infiltrate to native soils via the pervious rail bed underlying the rail spur. The monitoring device set up at the "Seep" was identical to that of the "Pond Outlet" site. A fourth monitoring point ('LaPlatte at Seep') was established in July 2018 in the LaPlatte River adjacent to the location of the seep. An AquaTroll 200 measuring conductivity and temperature in 15-min increments was installed in a perforated PVC monitoring device in the water at the edge of the river and anchored to 2 steel stakes driven into the bed of the River. All equipment was calibrated monthly following factory calibration standards and data was downloaded for processing at the same time. During periods of hard freezing conditions,

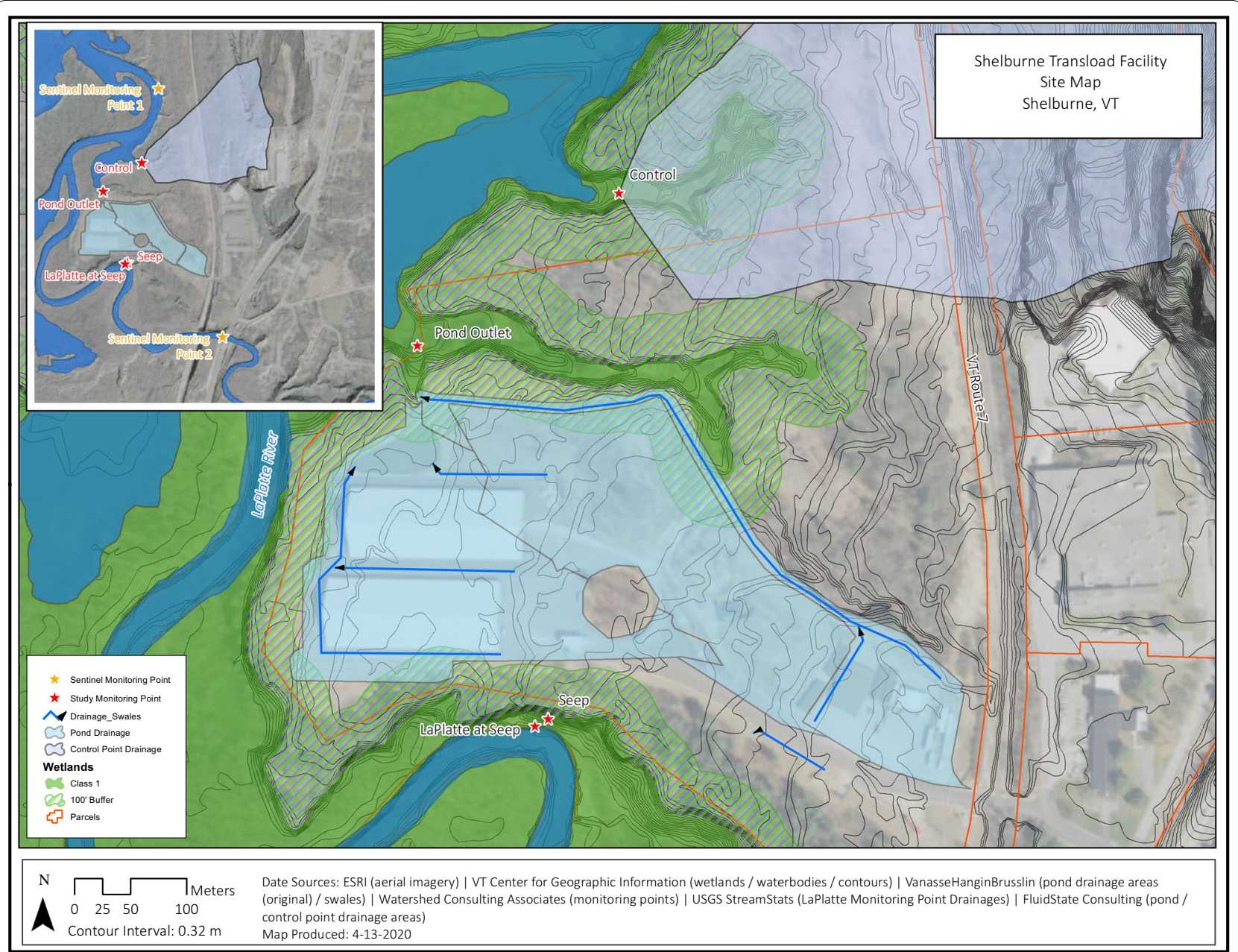

Fig. 2 Shelburne transload facility site and drainage area map for "Pond Outlet" and "Control" monitoring points 
probes were removed from the field to avoid damage to equipment.

Measuring the electrical conductivity of water determines how well an electrical current passes through it the solution. There is a linear relationship between water's electrical conductivity and the concentration of dissolved ions. This relationship can be used to calculate chloride concentrations when conductivity is measured. A regression equation can be developed for a monitoring point by measuring conductivity with a probe and taking grab samples for lab analysis of chloride concentration. This approach requires sampling over a wide range of concentrations to ensure accuracy. The State of Vermont's Department of Environmental Conservation developed a regression equation for use in determining chloride pollution in waters of the State (Eq. 1) that has been shown to be accurate in most surface waters in Vermont. This study makes use of the State equation to convert continuous conductivity measurements to chloride concentrations (VT DEC 2019).

$$
\text { chloride }\left(m g L^{-1}\right)=0.292 * \operatorname{specificconductivity~}\left(\mu \mathrm{Scm}^{-1}\right)
$$

The regulatory thresholds are calculated based on moving averages (chronic standard concentration of $230 \mathrm{mg} \mathrm{L}^{-1}$ is based on a 4-day moving average and the acute concentration of $860 \mathrm{mg} \mathrm{L}^{-1}$ is a 1-h moving average) and require measurement in 15-min increments. Therefore, in order to determine threshold exceedance, continuous data of the type collected during this study must be used.

Grab samples from each site were taken during monthly field visits. The "Control" site was intermittently dry and was therefore not sampled during some periods. Samples were collected in duplicate in $50 \mathrm{~mL}$ plastic vials, triple rinsed, labeled, and stored on ice for immediate transport (AWWA, APHA, WEF 1992). Laboratory analysis was performed by Endyne Laboratories in Williston, Vermont using EPA Method 300.0, Determination of inorganic anions by Ion Chromatography (Pfaff 1993).

\section{Soil testing}

Soil cores were collected by soil auger at 3 locations within $10 \mathrm{~m}$ of the monitoring devices at the "Control", "Pond Outlet", and "Seep" sites. Cores were taken to a depth of $30 \mathrm{~cm}$, visually characterized, and subsampled into labeled plastic bags and transported on ice to the Agricultural and Environmental Testing Laboratory (AETL) at the University of Vermont. Available soil $\mathrm{Cl}^{-}$ was extracted with $\mathrm{CaNO}_{3}$ and analyzed with Mercury (II) Thiocyanate colorimetric method (Goodrich et al.
2009). Total $\mathrm{Mg}^{2+}, \mathrm{Na}^{+}$, and $\mathrm{K}^{+}$were measured using nitric acid/ hydrogen peroxide digestion and ICP-AES.

\section{Vegetation testing}

Hemlock (Tsuga canadensis) needle and twig samples were collected from 5 trees of varying size and age within a $60-\mathrm{m}$ radius of the monitoring devices at the "Control", "Pond Outlet", and "Seep" sites. Tree diameter at breast height (DBH), linear distance from water sampling location, and visual qualitative assessment of health were recorded for each. Needle and twig samples were collected from the crown, middle, and lower branches. Branch samples were stored in clean, labeled plastic bags for transport on ice to the AETL at the University of Vermont. Vegetation was oven dried at $85{ }^{\circ} \mathrm{C}$ for $72 \mathrm{~h}$ and sieved using a $2.0 \mathrm{~mm}$ sieve. Available $\mathrm{Cl}^{-}$was extracted using $\mathrm{CaNO}^{3}$ and analyzed by ICP-AES.

\section{Temperature and rainfall}

Weather data (air temperature and hourly rainfall totals) were obtained through the Northeast Regional Climate Center (NRCC). Data is derived from the Automated Surface Observing Systems (ASOS) program which is a joint effort of the National Weather Service (NWS), the Federal Aviation Administration (FAA), and the Department of Defense (DOD). The ASOS systems serves as the nation's primary surface weather observing network. ASOS is designed to support weather forecast activities and aviation operations and, at the same time, support the needs of the meteorological, hydrological, and climatological research communities. The nearest ASOS station is located at the Burlington International Airport in Burlington, VT, approximately $14.5 \mathrm{~km}$ to the northeast of the study site.

\section{Results}

\section{Chloride concentrations-grab sampling}

Chloride concentrations varied between sampling sites. The "Control" site was consistently low and below US EPA regulatory thresholds for acute $\left(860 \mathrm{mg} \mathrm{L}^{-1}\right)$ and chronic $\left(230 \mathrm{mg} \mathrm{L}^{-1}\right)$ impacts. The mean concentration of chloride (from laboratory analysis of grab samples) at the "Control" site was $11 \mathrm{mg} \mathrm{L}^{-1}$ while concentrations in the "LaPlatte" River site averaged $33 \mathrm{mg} \mathrm{L}^{-1}$. The two monitoring locations collecting runoff from the STF measured significantly higher, with the "Pond Outlet" averaging $243 \mathrm{mg} \mathrm{L}^{-1}$ and the "Seep" averaging $643 \mathrm{mg} \mathrm{L}^{-1}$ (both above US EPA standards for chronic toxicity) Table 1 . Acute toxicity levels were exceeded for 9 discrete sampling events at the Seep (31\% of the total grab samples). Chloride concentration values from "Seep" and "Pond Outlet" exceeded "Control" ( $\mathrm{p}<0.0001$ and $\mathrm{p}=0.0001$ respectively) Fig. 3 . 
Table 1 Water grab sample summary for study locations

\begin{tabular}{llll}
\hline Site & $\mathbf{n}$ & Mean $\left(\mathbf{m g ~ L}^{\mathbf{- 1}}\right)$ & $\mathbf{M i n} \mathbf{m a x}(\mathbf{m g ~ L}$ \\
\hline Control & 12 & 11 & $6.1 / 13.5$ \\
Pond outlet & 34 & 243 & $18 / 380$ \\
Seep & 29 & 643 & $140 / 1450$ \\
LaPlatte & 19 & 33 & $19 / 45$ \\
\hline
\end{tabular}

\section{Chloride concentration-continuous conductivity measurement}

The continuous conductivity measurements corroborate findings from the grab sampling while illuminating fluctuations in the data between grab samples that cannot be seen with intermittent sampling alone. Most notably, the continuous conductivity measurements illustrate the sinuous pattern of chloride concentrations at the "Seep" which peaks in mid-summer and decreases during freezing winter periods and spring melt.

In general, the "Seep" was found to have the highest concentrations of chloride seen at any site during the 2 years. Over the monitoring period, water at this site exceed the US EPA chronic standard for chloride impairment a total of 227 days and the acute standard a total of $695 \mathrm{~h}$ (approximately 29 days) (see Additional File 2 for graphs of continuous conductivity and calculated chloride at the Seep).

Chloride concentrations at the "Pond Outlet' were generally higher than the US EPA chronic standard with a total number of days of exceedance at 198. The acute standard was not exceeded at this site. During spring flood periods, the concentration of chloride at this site was at its lowest point due to dilution from backflooding by river and lake water (See Additional file 3).

Chloride concentrations at the "Control" site were generally low when flow was present. The "Control" site was dry during much of the summer monitoring periods, reducing the amount of data for that site. This discrepancy is likely a result of the forested nature of the "Control" site and the sandy loam soils that characterize its drainage area which readily absorb precipitation. Overall, the "Control" was characterized by very low chloride concentrations $\left(31 \mathrm{mg} \mathrm{L}^{-1}\right)$ and no regulatory standard exceedances (See Additional File 1).

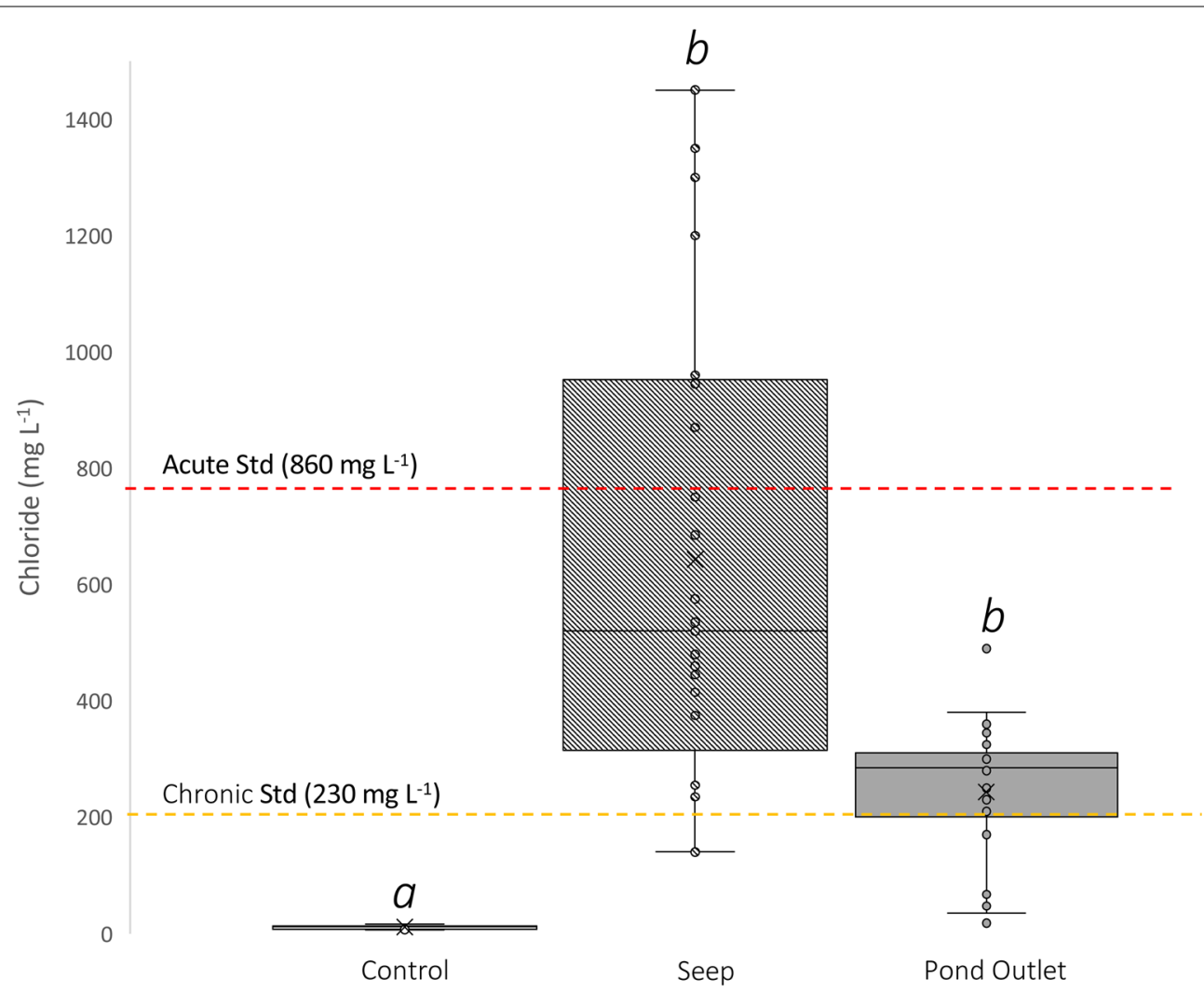

Fig. 3 Chloride concentrations for water grab samples at the "Control," Seep," and "Pond Outlet" sites. Difference in letters denotes statistical significance at $a \leq 0.05$. The "LaPlatte" monitoring point data is not included in this graph due to the nature of the sample type (taken in a river) differing significantly from the other sampling locations 
The "LaPlatte" monitoring point is within the LaPlatte River at the uppermost discharge point ("Seep) from the STF. The average chloride concentration at "LaPlatte" is $22 \mathrm{mg} \mathrm{L}^{-1}$. No samples from "LaPlatte" exceeded regulatory standards (see Additional File 4).

\section{Chloride concentration-soil sampling}

The concentration of chloride in the soils and the associated pore water at the "Control" was lower than both test sites $(p=0.032$ and $p=0.035$ for the "Seep" and "Pond Outlet" respectively) which is similar to patterns observed in chloride concentrations in water samples at these sites. Analysis of commonly associated cations in road salt indicate higher sodium $\left(\mathrm{Na}^{+}\right)$concentrations in the soils at the "Pond Outlet" than the "Control" $(p=0.0002)$ or the "Seep" $(p=0.0006)$ while magnesium $\left(\mathrm{Mg}^{2+}\right)$ did not differ significantly between the "Control" and "Seep" $(\mathrm{p}=0.640)$ or the "Control" and "Pond Outlet" $(\mathrm{p}=0.070)$. Potassium $\left(\mathrm{K}^{+}\right)$concentrations also do not differ significantly between "Control" and "Seep" $(\mathrm{p}=0.248)$ or "Control" and "Pond Outlet" $(\mathrm{p}=0.478)$ Fig. 4.

The similarity in chloride concentration patterns between soil and water samples at each monitoring point confirms chloride's behavior as a stable tracer ion most significantly influenced by hydraulic gradients.

\section{Chloride concentration-vegetation}

Vegetation (Hemlock, Tsuga canadensis) samples at the "Control" indicate significantly lower chloride concentrations in twig and needle samples than samples obtained in the vicinity of the "Seep" $(p=0.006)$ or the "Pond Outlet" $(p=0.027)$ Fig. 5 .

Visible signs of vegetation 'salt burn' where leaves and needles turn brownish-orange are evident at the "Seep" and "Pond Outlet" but additional assessment of the extent of vegetation impacts is needed to determine if there is a correlation between twig and needle chloride concentration and visually observed 'salt burn' or premature death.

\section{Discussion}

\section{Water quality monitoring}

The significant difference in analyzed grab sample chloride concentrations between the "Control" and "Seep" ( $\mathrm{p}<0.0001)$ and the "Control" and "Pond Outlet" $(\mathrm{p}=0.0001)$ sites across the two-year study period indicates an apparent impact from the adjacent STF.

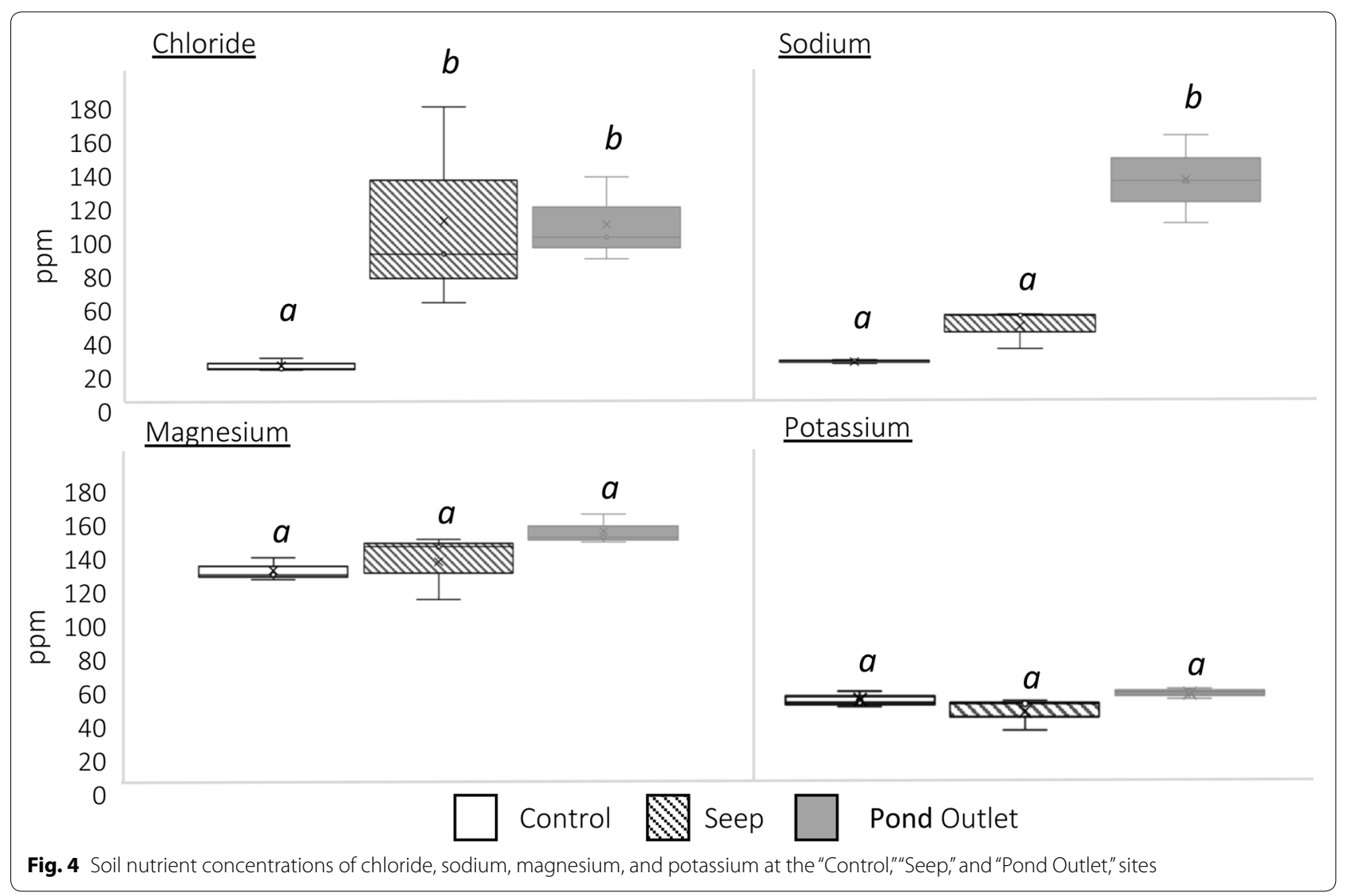




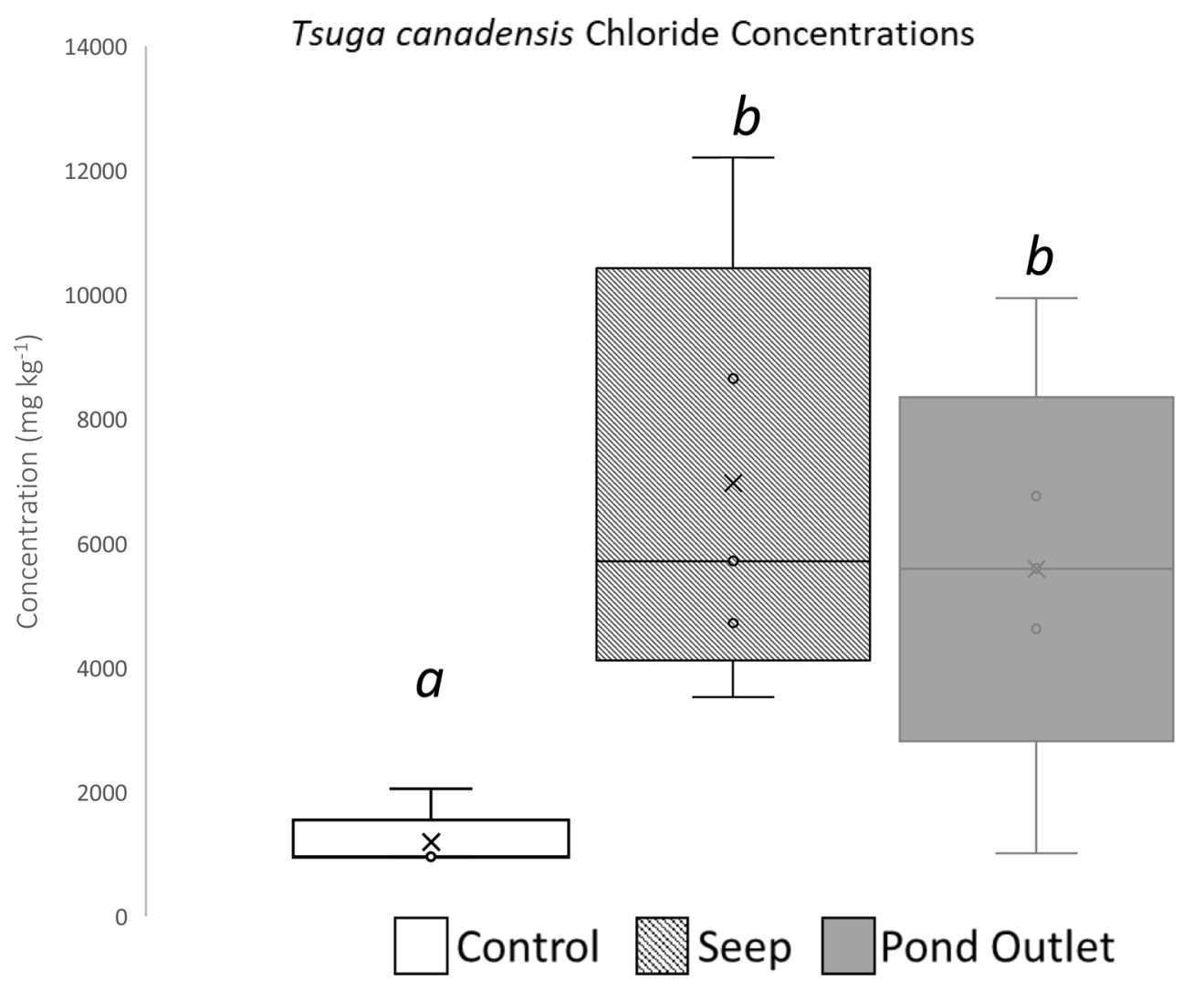

Fig. 5 Chloride concentrations in Tsuga canadensis needle and twig samples. Different letters denote statistically significant difference

On average, grab samples from the "Control" and the "Seep" are above US EPA standards for chronic toxicity, with several samples above acutely toxic levels at the "Seep," a trait never observed at the "Control" site.

Continuously measured conductivity results are consistent with findings from the grab sampling efforts. Chloride concentrations at the "Seep" site exceeded the US EPA acute standard of $860 \mathrm{mg} \mathrm{L}^{-1}$ in the early part of year 1 , in addition to exceeding the chronic standard. Concentrations then decreased overall from year 1 to year 2, potentially due to the installation of a roof over the 'salt offloading' area located along the STF's rail spur (in late 2018 or early 2019). Prior to roof installation, salt spilled during unloading could accumulate on the pervious rail bed and infiltrate into native soil during precipitation events. Given the high ratio of salt to water (precipitation), the lack of treatment by any stormwater management features (the area under the rail bed is not hydrologically connected to the STF's stormwater management features), and the proximity of the "Seep" at 4 vertical and 37 horizontal meters away, high concentrations of chloride appear to daylight at the "Seep" and are readily transported into the LaPlatte River.
The high chloride concentrations at the "Seep" seen in year 2 during spring 2018 that do not track with conductivity measurements may be related to sampling method. Prior to monitoring device installation, samples were collected from surface water at the "Seep" itself where groundwater emerges at the toe of a slope. After the continuous conductivity monitoring device was installed, grab samples were collected from within the vertical chamber (similar to a shallow groundwater well). Grab samples taken prior to the installation of the monitoring device may have been more turbid due to their collection from the surface at the seep itself and without filtration through the monitoring device fabric and stone layer. This may have resulted in the higher $\mathrm{Cl}^{-}$concentration values taken before the monitoring device was installed and may explain the comparatively higher values on the early dates of the study. Therefore, concentrations measured in the sampling device for the majority of the study may be more conservative (lower) than direct surface measurements from the "Seep."

Where concentrations at the "Seep" varied seasonally and decreased from year 1 to year 2, "Pond Outlet" concentrations remained relatively constant throughout the 2 years and are nearly always above the US EPA 
chronic standard. The low concentrations observed at the "Pond Outlet" in spring periods are likely due to flooding from Lake Champlain and the LaPlatte River. Floodwaters inundate the "Pond Outlet" monitoring site and dilute the water within. When flooding subsides, chloride concentrations return to above-chronic levels. No significant fluctuation is evident throughout the rest of the study period and chloride concentrations are not notably influenced by precipitation or temperature alone, which differs from patterns observed in other chloride investigations in urban areas draining streets and parking lots where deicing salts are applied following periods of winter precipitation and higher chloride concentrations are subsequently observed during melt periods (temperature-driven) or during and following rain (precipitation-driven) (Torizzo et al. 2016; Mayer et al. 1999). By contrast, the STF receives and stores deicing salts yearround. Salt spillage on impervious surfaces is possible in all seasons and transport to the pond may be occurring consistently, rather than only during winter and early spring periods.

Additionally the conveyance mechanisms for runoff may influence chloride concentrations at the stormwater pond as some of the swales routing runoff are pervious, allowing infiltration of some of the volume and its associated chloride concentration to groundwater. This may indicate that chloride concentrations measured at the "Pond Outlet" are conservative with respect to the total amount of chloride being transported from the STF via surface and sub-surface flows.

\section{Soils}

Soils data provide a point of comparison to water quality concentration information. Concentration of ions associated with deicing salts in soils are less ephemeral than concentrations in water. The accumulation and retention of ions in soils can illustrate loading to the environment in a way that measuring concentration in water alone cannot (Ostendorf et al. 2009).

Concentrations in water are greatly influenced by contributing drainage area. In the case of the sentinel monitoring point chosen by the State agency for permitting, a large watershed with relatively uncontaminated runoff seems to easily mask the chloride signal from the STF. The soils data from sites immediately below the "Pond Outlet" and "Seep" show a different story. This indicates that the choice of monitoring location for chloride must take dilution into account as localized impacts to soil chemistry, vegetation, and associated aquatic and riparian species, will not be accounted for.

The elevated levels of $\mathrm{Na}^{+}$at both test sites ("Pond Outlet" and "Seep") confirm that the dominant form of deicing salts transported and stored in the adjacent facility are sodium chloride compounds (commonly known as 'rock salt'). $\mathrm{Na}^{+}$concentrations are higher at the "Pond Outlet" than the "Seep" or the "Control" likely due to the collection and concentration of runoff from the STF site through the stormwater pond, resulting in higher loading to the wetland where the stormwater pond discharges. While water concentrations of $\mathrm{Cl}^{-}$are not as elevated at the "Pond Outlet" as they are at the "Seep," much higher volumes of water flow through the "Pond Outlet" point, resulting in lower $\mathrm{Cl}^{-}$concentrations in water but because $\mathrm{Na}^{+}$will bind to soil particles, higher concentrations of that ion were measured in the wetland soils, indicating that $\mathrm{Na}^{+}$may be disproportionately loading and displacing native soil cations. This loading impact can't be observed from measurements of water samples alone as water and its associated chloride concentrations are transient.

No statistically significant difference in $\mathrm{Mg}^{2+}$ in soils among any of the sites was observed which may indicate that $\mathrm{MgCl}$ is not the most common salt stored at the site. This is supported by national deicing salt usage which defaults to $\mathrm{NaCl}$ due to its lower cost. There is a trend in the $\mathrm{Mg}^{2+}$ data towards significant difference between the "Pond Outlet" and the "Control" $(\mathrm{p}=0.07)$, indicating that over time the $\mathrm{Mg}^{2+}$ ratio in native soils may be similarly changed as a result of deicing salts, but this may take longer than $\mathrm{Na}^{+}$to appear due to an overall lower volume held on site.

$\mathrm{K}^{+}$serves as a comparison cation to show likely native conditions of soils on and surrounding the STF. There is no difference for this cation among all monitoring sites, indicating that in natural conditions the soils at the three sites would likely have had very similar soil cation ratios (i.e. for $\mathrm{Na}^{+}, \mathrm{Mg}^{2+}$, and $\mathrm{K}^{+}$). Because the soils at each site are mapped as the same type by published USGS Soil Survey maps (Adams and Windsor loamy sands) the relative abundance of each cation would be consistent without influence by the STF. $\mathrm{K}^{+}$may be in danger of displacement by $\mathrm{Na}^{+}$and $\mathrm{Mg}^{2+}$ within the native soils over time which could be damaging to soil microbial communities and vegetation.

The lack of soil sampling and analysis in the site's permit compliance documents (as required by the State stormwater program) eliminates use of a more suitable media for tracking pollutant movement from the site on a time scale that could allow remediation.

\section{Vegetation}

Other studies have linked increased chloride concentrations in vegetation to thinning, reduced diversity, and physiological changes resulting in poor performance/ survival (Labashosky 2015; Meter et al. 2011, 2012). Tsuga canadensis are a salt sensitive species and therefore 
may offer an early indication of impact to the wetland at large (USDA). Additional study focused on vegetation, species diversity, and chloride impacts is needed to conclusively determine the extent of influence from salt loading.

\section{Monitoring program}

Despite these clear impacts, the operators of the STF have not indicated to the regulatory authority (VT DEC) that there are any issues resulting from the salt storage facility, attributable to the monitoring point locations and methods. This is in part due to a misapplication of stated water quality management strategy on the part of VT DEC to designate an adequate monitoring point or protocol. As previously noted, the designated sentinel monitoring point is downstream of the STF and subject to considerable dilution from the drainage area. This point forms part of VT DEC's Integrated Water Information System (IWIS) which is part of the State's Water Quality Monitoring Program Strategy (VT DEC 2019). The Strategy document discusses the four types of points which are typically designated as monitoring points including 'targeted' sites chosen for a specific reason such as stream sections or water body discharge with known problems, 'probability' sites which are chosen based on their likelihood to have a water quality issue, 'river geomorphic assessment' sites which are targeted for geomorphologic changes, and 'special or Total Maximum Daily Load (TMDL) studies' sites which are chosen based on specific changes in pollutant load potential or need to demonstrate compliance with a TMDL mandate. This last site type could apply specifically to the STF site and its concentration of deicing salt storage. However, VT DEC chose not to exercise its stated strategy in designating the sentinel monitoring point but rather chose to use a legacy 'targeted' point located near the mouth of the LaPlatte River.

As an EPA designated permit authority, VT DEC also had the option to designate the stormwater BMP 'outfall' as a monitoring point in addition to a downstream monitoring point, in accordance with EPA guidelines. However, this was not done, nor was a designation of the Class I wetland as the 'closest waterway' exercised as an option as advised under EPA guidelines. Rather, the operator of the STF was allowed to designate monitoring points. This is a known and documented issue with water quality permit compliance monitoring programs as noted by the federal Government Accounting Office (GAO) in 1981 in their finding that better monitoring techniques were needed to assess the quality of rivers and streams. Though improvements have been made, this site illustrates that best practices are not consistently followed and inconsistent oversight leads, as in this case, to pollutant loading.

There are established 'use cases' for planning or optimizing an effective Water Quality Monitoring Program (WQMP). While no WQMP will work in all cases, there are common practices that managers can follow. Research indicates that "it is essential that water quality data be relevant, precise and reliable in space and time" and that "watershed managers [have to] adapt their WQMPs to evolving issues of water quality." Further, "water bodies should not be separated when planning or optimizing and WQMP as rivers feeds lakes and vice versa." It is logical to extend this connection to other hydrologically connected water bodies such as wetlands and groundwater. A nascent tenet in environmental regulation posits that "the objective is no longer mainly to measure the concentration of chemicals: more and more the objective is shifting towards the evaluation of ecological integrity and the effects of the chemical mixtures" (Behmel et al. 2016).

One such WQMP strategy that could have been employed in this case is outlined in detail by Strobl et al. in a 2006 research paper documenting the use of a 'Critical Sampling Point (CSP) methodology which takes into account surface and sub-surface conditions and applies 'fuzzy' logic to account for real-world lack of distinct boundaries between topographic and land use features which can influence pollutant runoff (Strobl et al. 2006). The model also addresses logistical and economic (cost of monitoring) concerns. The CSP methodology represents just one WQMP strategy that could be employed to designate a more appropriate monitoring point under the VT DEC's 'probability' site strategy protocol.

\section{Stormwater BMPs and chloride reduction performance}

Stormwater Best Management Practices (BMPs) aim to reduce the volume of pollutants discharged from a site. The two practices selected for use on this site, a stormwater wet detention pond and a swale with level spreader, were inappropriately employed. The literature has conclusively found these control structures ill suited to reducing salt concentrations due to chloride's chemical properties.

Barbier et al., in a study of stormwater retention ponds treating deicing salts from roadways found that "almost all of the deicing salt entering the basin was evacuated at the end of March (91\%)" and sodium was not retained in pond sediments (Barbier et al. 2018). A similar study from 2006 in Sweden found that "continuous conductivity measurements show that chloride is flushed between [precipitation] events" (Semadeni-Davies 2006). North Carolina's Department of Transportation specifically reviewed BMPs for salt storage sites in 2006, finding that "runoff from a salt storage area had elevated levels of 
chloride indicating the need for improved containment of salt" (Line 2006). The same study noted that none of the BMPs used to treat (not contain) salt had any significant effect on conductivity.

Snowmelt storage sites are similar to deicing salt storage facilities in that a relatively small area receives and stores a large amount of deicing salt (in the case of snowmelt storage sites, deicing salts contained within plowed snow and ice transported to the site via truck). A Canadian study from 2019 investigated the effect of a treatment train approach to reducing chloride pollution (Senior et al. 2019). The train, consisting of an impervious melting pad, forebay and grit separator, and extended detention wet pond, served only to dilute, not reduce, chloride concentration through detention of high $\mathrm{Cl}$ concentration meltwater and mixing with cleaner precipitation-based runoff from the pad.

Other entities have recognized the inutility of typical stormwater BMPs at salt storage sites. The Virginia Department of Transportation (VDOT) evaluated their treatment approaches which typically consist of wet ponds used to temporarily store high $\mathrm{Cl}$ concentration runoff for later treatment either at a public treatment works system or for application on gravel roads for dust suppression (Müller and Gächter 2012). This paper also concluded that their current system is cost-prohibitive and advocated for the development of on-site reverseosmosis treatment to remove dissolved salts from runoff.

\section{Conclusions}

The STF salt sheds are loading chloride and other ions to surface and shallow ground water, as well as soils and vegetation adjacent to the facility. The discharge water at the "Pond Outlet," which is one of the two designated stormwater discharge points for the site, exceeded US EPA water quality standards for chronic chloride impairment for a total of 198 days. Similarly, water measured at the "Seep" was above the US EPA chronic standard a total of 227 days and exceeded the acute standard a total of $695 \mathrm{~h}$. The "Control" site was well below any state or federal $\mathrm{Cl}$ concentrations standards throughout the study period.

The ions associated with the deicing salts stored on site are altering native soil chemistry, as evidenced by soil analysis indicating high chloride and sodium concentrations in the wetland in proximity to the discharge points. The corresponding visual assessment and leaf and twig chemical analysis indicate that trees in proximity with the site have higher chloride concentrations and also anecdotally show signs of leaf burn.

The results from this study are similar to other studies that have focused on salt storage facilities as point sources of chloride in water and soil media (Ostendorf et al. 2009; Ohno 1990). The potential impact of salt storage sites on water quality and native soil chemistry is known, but regulatory enforcement is not adequately protecting natural resources due to inadequate oversight and misapplication of existing tools to track pollutants.

Appropriate management of this and similar sites includes selection of suitable monitoring locations and mediums to accompany site operation. STF's annual reporting document reports that water quality measurements in the LaPlatte River at the sentinel monitoring location did not exceed the US EPA's chronic or acute threshold during the first year of operation, presented as evidence that the site was not negatively impacting water quality. The results of the study detailed here are in direct opposition to STF's monitoring. Because this site is operating in compliance with permit requirements, despite clear evidence of impacts to water quality, soils, and vegetation, it is continuing to discharge excessive levels of chloride without sufficiently protective regulatory control.

The most significant difference between the monitoring approach taken by the STF and what was employed in this study is in the selection of the point at which water quality is measured and regulatory exceedance determined. The STF, as approved by the VT DEC, selected an instream point nearly $1 \mathrm{~km}$ downstream from the points of discharge. The drainage area of the LaPlatte River at the point at which that monitoring occurred is three orders of magnitude larger than the STF campus itself (approximately $87,850 \mathrm{~km}^{2}$ ). The downstream nature of the selected point of water quality assessment makes it unlikely that any signal from excess chloride discharge from the STF site will be evident until the problem is significant and irreversible. The monitoring locations in this study are in close proximity to the discharge points from the site but within the receiving water bodies, making them more localized measures of ecological impact and allowing more immediate detection of water quality standard exceedances, which could result in corrective actions on an appropriate timescale. The variance in conclusions between this study and the STF results highlight the potential negative impact of variable regulatory methods being used to control chloride discharges from storage and transport facilities in different locales.

Continuous water monitoring can be challenging, costly, and subject to cold-temperature limitations of equipment. Further, where a receiving water body subject to water quality standards is far away from a site or is difficult to access, monitoring surface waters may provide information with a time lag that does not allow for operational adjustments that could protect environmental systems. Soils analyses at regular (yearly) intervals could serve as a more stable measure of chloride (and sodium 
and magnesium) export and movement from a discharge point. Soils offer information about loading that is more elusive with water sampling alone when it lacks concurrent flow and discharge records. In this study, where the highest chloride concentrations in water samples were measured at the "Seep," the "Pond Outlet" site soils analysis results indicate higher loading due to the discharge of a greater volume of polluted water. Assessing loading to receiving areas can be as or more important than assessing concentration alone as the legacy effects of deicing salt pollution may be present long after transient water pollution has been abated (Mayer et al. 1999). Emerging evidence suggests that even with salt application reduction, elevated surface water concentrations of $\mathrm{Na}+$ and $\mathrm{Cl}-$ can persist for decades due to soil and groundwater storage and release (Kelly et al. 2019).

The changes to native soil chemistry may have impacts to vegetation directly or indirectly (Volkmar et al. 1998). While this study found increased concentrations of chloride in the leaves and twigs of one vegetation type, the connection between salt loading and species diversity, reproduction, and survival should be explored to understand what is most at risk and the mechanisms responsible. The high ecological quality of the wetland studied in this investigation deserves particular focus on impacts to rare and protected species of plants, fish, and amphibians that may be particularly sensitive to increased salinity.

This study clearly illustrates that selection of monitoring point locations can make a significant impact on the determination of exceedances of surface water quality standards. Where the monitoring point location is removed from a regulated discharge point or points and is influenced by a much greater drainage area, surface and ground water input can mask underlying concentrations and loading issues via dilution. In the snowy and cold northern regions of the United States, there are hundreds of deicing salt storage facilities. Without consistent and scientifically defensible standards for regulating these facilities, their water quality impacts will continue without oversight or appropriate control. The storage facility studied here includes fully covered salt piles-a feature that is not always present at similar facilities. Despite precipitation exclusion from the salt piles, export of ions associated with rock salt from this site is significant and in excess of water quality standards, causing irreparable damage to a sensitive and important freshwater resource. An inventory of deicing salt storage and transportation facilities is needed that details operational standards and proximity to surface waters, coupled with more appropriate water quality monitoring points in order to understand the extent of impact and develop effective approaches to limiting continued salinization effects. A unified approach to regulating and inspecting these facilities could eliminate the divergent findings from a single site such as was found in this study.

\section{Supplementary information}

Supplementary information accompanies this paper at https://doi. org/10.1186/s40068-020-00185-2.

Additional file 1. Continuous conductivity converted to chloride and chloride grab sample results at the Control site. Where no data are present indicate dry or freezing conditions. Note the lower value of grab samples when compared to continuous measurements is an indication of the insufficiency of the regression equation to accurately describe chloride concentrations from conductivity measurements when they are very low.

Additional file 2. Continuous and grab samples analyzed for chloride at the Seep site. Measurements exceeded USEPA chronic and acute standards on several occasions. Overall, concentration of chloride is decreasing likely due to the installation of a roof over the unloading area reducing rainfall onto the railbed where fallen salt is evident.

Additional file 3. Continuous conductivity and chloride values as well as chloride grab samples values at the Pond Outlet site. Measurements consistently exceeded USEPA chronic standards. A sudden drop in concentration is evident in spring of both years corresponding to high lake levels causing back watering into the monitoring site.

Additional file 4. Continuous conductivity converted to chloride and intermittent chloride grab sample results at the LaPlatte at Seep site (within the river). Monitoring at this site started later than the others, and includes 13 months of data. Concentrations are below the USEPA chronic standard but is consistently higher than the Control site. The large size of the watershed draining to the river at this point contributes to the difficulty of using it as a monitoring point to assess inputs from adjacent land uses.

Additional file 5. Raw water quality data

Additional file 6. Vermont Rail Shelburne Transload Facility Stormwater Pollution Prevention Plan document.

\section{Abbreviations}

AETL: Agricultural and Environmental Testing Laboratory; ASOS: Automated Surface Observing Systems; DOD: Department of Defense; FAA: Federal Aviation Administration; MSGP: Multi Sector General Permit; NPDES: National Pollution Discharge Elimination System; NRCC: Northeast Regional Climate Center; NWS: National Weather Service; PVC: Polyvinyl chloride; STF: Shelburne Transload Facility; SWPPP: Stormwater Pollution Prevention Plan; US EPA: United States Environmental Protection Agency; USGS: United State Geological Survey; VT DEC:Vermont Department of Environmental Conservation.

\section{Authors' contributions}

RT designed the study, supervised field data collection and data digestion, and performed data analysis and display while working for Watershed Consulting Associates, LLC. RT subsequently refined data analysis and display and carried out all statistical analysis while at Just Water Consulting, LLC. DA was responsible for review of literature associated with this article, as well as analysis of geographic data to support analysis. Conceptualization, RT; methodology, RT; formal analysis, RT.; investigation, RT; resources, RT, DA; data curation, RT.; writing —original draft preparation, DA, RT; writing — review and editing, $D A$, RT; funding acquisition, DA. All authors have agreed to the published version of the manuscript. All authors read and approved the final manuscript.

Funding

This research was funded by the Lintilhac Foundation.

\section{Availability of data and material}

The datasets supporting the conclusions of this article are included within the article (and its additional files). Additional figures of continuous chloride, temperature, and rainfall data are also available as Additional files 1, 2, 3, 4, 5, 6 . 
Ethics approval and consent to participate Not applicable.

\section{Consent for publication}

Not applicable.

\section{Competing Interests}

DA has a non-financial competing interest, as he is related by marriage to members of the Board of the Lintilhac Foundation that funded this work. RT declares that she has no competing interests associated with this project. As RT designed, directly measured, and analyzed this project's data, the authors confidently assert that the relationship of DA has had no influence on the findings of this study or its presentation. The funders had no role in the design of the study; in the collection, analyses, or interpretation of data; in the writing of the manuscript, or in the decision to publish the results".

\section{Author details}

${ }^{1}$ Just Water Consulting, Vermont, USA. ${ }^{2}$ FluidState Consulting, Vermont, USA.

Received: 15 April 2020 Accepted: 15 September 2020

Published online: 24 September 2020

\section{References}

Albecker MA, McCoy MW (2017) Adaptive responses to salinity stress across multiple life stages in anuran amphibians. Front Zool. 14:1-6

AWWA, APHA, WEF (1992) Standard methods for the examination of water and wastewater. 18th ed

Barbier L, Suaire R, Durickovic I, Laurent J, Simonnot MO (2018) Is a road stormwater retention pond able to intercept deicing salt? Water Air Soil Pollut. 229:251

Behmel S, Damour M, Ludwig R, Rodriguez MJ (2016) Water quality monitoring strategies - a review and future perspectives. Sci Total Environ. 571:1312

Bolen WP (2015) US Geological Survey Minerals Yearbook 2015: salt. https:// s3-us-west-2.amazonaws.com/prd-wret/assets/palladium/production/ mineral-pubs/salt/myb1-2015-salt.pdf

Brown AH, Yan ND (2015) Food quantity affects the sensitivity of Daphnia to road salt. Environ Sci Technol. 49:4673

Cañedo-Argüelles M, Kefford BJ, Piscart C, Prat N, Schäfer RB, Schulz CJ (2013) Salinisation of rivers: an urgent ecological issue. Environ Pollut. 173:157

Castillo AM, Sharpe DMT, Ghalambor CK, De León LF (2018) Exploring the effects of salinization on trophic diversity in freshwater ecosystems: a quantitative review. Hydrobiologia 807:1-7

Corsi SR, Graczyk DJ, Geis SW, Booth NL, Richards KD (2010) A fresh look at road salt: aquatic toxicity and water-quality impacts on local, regional, and national scales. Environ Sci Technol. 44:7376

Crowther RA, Hynes H (1977) The effect of road deicing salt on the drift of stream benthos. Environ Pollut 14:113

Department of Environmental Conservation V (2016) Class I Determination Rulemaking Decision Petition for the reclassification of the LaPlatte River Marsh Complex from Class II to Class I with a 100-foot buffer zone

Dugan HA, Bartlett SL, Burke SM, Doubek JP, Krivak-Tetley FE, Skaff NK et al (2017) Salting our freshwater lakes. Proc Natl Acad Sci USA 114(17):4453-4458

Ellis CR, Champlin J, Ste HG (1997) Density current intrusions in an ice-covered urban lake. J Am Water Res Assoc 33:1363

Eyles N, Meriano M (2010) Road-impacted sediment and water in a Lake Ontario watershed and lagoon, City of Pickering, Ontario, Canada: An example of urban basin analysis. Sediment Geol 224(1-4):15-28

Fitch G, Bartelt-Hunt S, Smith J (2005) Part 4: winter maintenance: characterization and environmental management of storm water runoff from road salt storage facilities. Transp Res Rec J Transp Res Board. 1911:125

Gillis PL (2011) Assessing the toxicity of sodium chloride to the glochidia of freshwater mussels: Implications for salinization of surface waters. Environ Pollut 159(6):1702-1708

Goodrich BA, Koski RD, Jacobi WR (2009) Condition of soils and vegetation along roads treated with magnesium chloride for dust suppression. Water Air Soil Pollut 198(1-4):165-188

Hanbali DA, Kuemmel RM (1993) Traffic volume reductions due to winter storm conditions. Transp Res Rec No 1387, Snow Remove Ice Control
Technology Paper Presented 3rd International Symposium on Snow Removal and Ice Control Technology Minneapolis, MN

Herbert ER, Boon P, Burgin AJ, Neubauer SC, Franklin RB, Ardon M et al (2015) A global perspective on wetland salinization: Ecological consequences of a growing threat to freshwater wetlands. Ecosphere. 6:1-43

Herricks EE, Schaeffer DJ, Kapsner JC (1985) Complying with NPDES permit limits: when is a violation a violation? Water Pollut Control Fed 57:109. https://about.jstor.org/terms

Highway Deicing and Calcium Committee on the Comparative Costs of Rock Salt and Calcium Magnesium Acetate (CMA) for Highway Deicing (1991) https://onlinepubs.trb.org/onlinepubs/sr/sr235/00i-012.pdf

Hintz WD, Relyea RA (2019) A review of the species, community, and ecosystem impacts of road salt salinisation in fresh waters. Freshw Biol 64:1081-1097. https://doi.org/10.1111/fwb.13286

Howard KWF, Maier H (2007) Road de-icing salt as a potential constraint on urban growth in the Greater Toronto Area Canada. J Contam Hydrol 91:146

Jackson RB, Jobbágy EG (2005) From icy roads to salty streams. Proc Natl Acad Sci USA 102:14487

Kaushal SS, Groffman PM, Likens GE, Belt KT, Stack WP, Kelly VR et al (2005) Increased salinization of fresh water in the Northeastern United States. Proc Natl Acad Sci USA 102(38):13517-13520

Kelly VR, Findlay SEG, Schlesinger WH, Menking K, Chatrchyan AM (2010) Road salt: moving toward the solution. Environ Prot 16. https://www.caryinstit ute.org/research/reports/road_salt_2010.pdf\%5CnVASSAR

Kelly VR, Findlay SE, Hamilton SK, Lovett GM, Weathers KC (2019) Seasonal and Long-Term Dynamics in Stream Water Sodium Chloride Concentrations and the Effectiveness of Road Salt Best Management Practices. Water Air Soil Pollut. 230:13

Kotalik CJ, Clements WH, Cadmus P (2017) Effects of magnesium chloride road deicer on montane stream benthic communities. Hydrobiologia 799:193

Labashosky S (2015) The salty truth: revealing the need for stricter road salt. Application and Storage Regulations in the United States. Vill Envtl 26:103.http://www.boston.com/business/technology/articles/2011/01/

Ledford SH, Lautz LK, Stella JC (2016) Hydrogeologic processes impacting storage, fate, and transport of chloride from road salt in Urban Riparian Aquifers. Environ Sci Technol 50(10):4979-88. https://syracusecoe.syr.edu

Liao P, Pierce C, Laracheid J (2002) Diet dynamics of the adult piscivorous fish community in Spirit Lake, lowa, USA 1995-1997. Ecol Freshw Fish 11:178-189

Line DE (2006) Evaluating BMPs for Treating Stormwater and Wastewater from NCDOT's Highways, Industrial Facilities, and Borrow Pits-Section I: Industrial Sites, Section II: Highway Sites. FHWA Rep

Mason CF, Norton SA, Fernandez IJ, Katz LE (1999) Deconstruction of the chemical effects of road salt on stream water chemistry. J Environ Qual. 28:82

Mayer T, Snodgrass W, Morin D (1999) Spatial characterization of the occurrence of road salts and their environmental concentrations as chlorides in Canadian surface waters and benthic sediments. Water Qual Res J Canada 34(4):545-574

Milone \& Macbroom Inc (2010) LaPlatte River Watershed Stormwater Infrastructure Study Chittenden County, VT

Müller B, Gächter R (2012) Increasing chloride concentrations in Lake Constance: characterization of sources and estimation of loads. Aquat Sci. 74:101

Novotny EV, Stefan HG (2012) Road salt impact on lake stratification and water quality. J Hydraul Eng. 138:1069

Ohno T (1990) Levels of total cyanide and $\mathrm{NaCl}$ in surface waters adjacent to road salt storage facilities. Environ Pollut 67:123-132

Ostendorf DW, Xing B, Kallergis N (2009) Cation exchange in a glacial till drumlin at a road salt storage facility. J Contam Hydrol 106(3-4):118-130

OWRC / SCCGW Salt Storage Workgroup (2013) State oversight of road salt storage in midwestern and northeastern U.S.

Panno SV, Hackley KC, Hwang HH, Greenberg SE, Krapac IG, Landsberger S et al (2006) Characterization and identification of $\mathrm{Na}-\mathrm{Cl}$ sources in ground water. Ground Water 44:176

Petranka JW, Francis RA (2013) Effects of road salts on seasonal wetlands: poor prey performance may compromise growth of predatory salamanders. Wetlands 33(4):707-715

Pfaff JD (1993) Method 300.0 determination of inorganic anions by lon Chromatography Environmental Monitoring Systems Laboratory office 
of Research and Development U.S. Environmental Protection Agency Cincinnati, $\mathrm{OH} 45268$

Prosser RS, Rochfort Q, Mclnnis R, Exall K, Gillis PL (2017) Assessing the toxicity and risk of salt-impacted winter road runoff to the early life stages of freshwater mussels in the Canadian province of Ontario. Environ Pollut 230:589-597

Ramakrishna DM, Viraraghavan T (2005) Environmental impact of chemical deicers - a review. Water Air Soil Pollut 166:49-63

Reddy KR, DeLaune RD (2008) Biogeochemistry of wetlands: science and applications. CRC Press, Boca Raton

Semadeni-Davies A (2006) Winter performance of an urban stormwater pond in southern Sweden. Hydrol Process. 20:165

Senior M, Scheckenberger R, Moore R (2019) Design and construction of a snowmelt management facility in southern Ontario. In: 16th International Environmental Specialty Conference 2018, Held as Part of the Canadian Society for Civil Engineering Annual Conference 2018

Shimshack JP (2014) The economics of environmental monitoring and enforcement. Annu Rev Resour Econ 6(1):339-360

Strobl RO, Robillard PD, Day RL, Shannon RD, McDonnell AJ (2006) A water quality monitoring network design methodology for the selection of critical sampling points: Part II. Environ Monit Assess. 122:319

Torizzo A, Allen D, Garvey K, Bruno K (2016) Monitoring and tracking chloride trends. Stormwater Magazine 2. https://www.stormh2o.com/home/artic le/13025322/monitoring-and-tracking-chloride-trends

USDA. Plants Database. https://plants.usda.gov/java/

US EPA (1988) Ambient Water Quality Criteria for Chloride-1988. Washington DC
US EPA (2020) State-specific water quality standards effective under the Clean Water Act (CWA). https://www.epa.gov/wqs-tech/state-specific-water -quality-standards-effective-under-clean-water-act-cwa

Van Meter RJ, Swan CM (2014) Road salts as environmental constraints in urban pond food webs. PLoS ONE 9:e90168

Van Meter RJ, Swan CM, Snodgrass JW, Van Meter RJ, Swan CM, Snodgrass JW (2011) Salinization alters ecosystem structure in urban stormwater detention ponds. Uraban Ecosyst 14:723-736

Van Meter RJ, Swan CM, Trossen CA (2012) Effects of road deicer ( $\mathrm{NaCl})$ and amphibian grazers on detritus processing in pond mesocosms. Environ Toxicol Chem. 31(10):2306-2310. https://doi.org/10.1002/etc.1949

Volkmar KM, Hu Y, Steppuhn H (1998) Physiological responses of plants to salinity: a review. Can J Plant Sci 78:17. www.nrcresearchpress.com

VT DEC (2019) Watershed Management Division. Vermont Surface Water Assessment and Listing Methodology in accordance with USEPA Guidance. Montpelier www.watershedmanagement.vt.gov

VT DEC (2020) Quality Monitoring Program Strategy May 2011 Interim Update-May 2015

Williams DD, Williams NE, Cao Y (2000) Road salt contamination of groundwater in a major metropolitan area and development of a biological index to monitor its impact. Water Res. 34:127

\section{Publisher's Note}

Springer Nature remains neutral with regard to jurisdictional claims in published maps and institutional affiliations.

\section{Submit your manuscript to a SpringerOpen ${ }^{\circ}$ journal and benefit from:}

- Convenient online submission

- Rigorous peer review

- Open access: articles freely available online

- High visibility within the field

- Retaining the copyright to your article

Submit your next manuscript at $\boldsymbol{\nabla}$ springeropen.com 